\title{
ANALISIS PENERAPAN ACTIVITY BASED MANAGEMENT UNTUK MENINGKATKAN EFISIENSI PADA HOTEL GRAN CENTRAL MANADO
}

\author{
Christanty J R Muskitta ${ }^{1}$, Jenny Morasa ${ }^{2}$, Stanly Alexander ${ }^{3}$ \\ ${ }^{1,2,3}$ Fakultas Ekonomi dan Bisnis, Jurusan Akuntansi, Universitas Sam Ratulangi, Jl. Kampus Bahu, Manado, \\ 95115, Indonesia \\ email : christantymus@icloud.com
}

\begin{abstract}
The creation of an increasingly advanced business world it affects the increasingly fierce business competition. This competition not only occurs in the manufacturing industry but also in the service industry. In order to survive and win the competition, the hotel must increase its competitive advantage with the efficiency of managing the activity without reducing the quality provided to the customer. Activity Based Management is a method to improve efficiency. The purpose of this research is to try to apply activity based management method to improve efficiency at Hotel Gran Central Manado by identifying activity after that in analysis including activity not value added, eliminated so that can be reduced. The method used is descriptive method. The result of the research by applying activity based management method, found in room division of activity which is not added value and doing cost reduction that is not added value so that the efficiency increase without reducing the quality of service given to the customer.
\end{abstract}

Keywords : Activity Based Management, Activity, Efficiency

\section{PENDAHULUAN}

Kemajuan yang sangat pesat pada dunia usaha dewasa ini tidak terlepas dari kemajuan teknologi di berbagai bidang kehidupan yang telah memacu terciptanya lingkungan industry yang maju. Dengan adanya kemajuan yang sangat pesat pada dunia usaha tersebut akan mendorong perekonomian, baik di tingkat nasional maupun internasional untuk menuju era perdagangan bebas, yang tentu saja hal tersebut akan berdampak pada peningkatan persaingan bisnis yang semakin ketat. Seiring dengan meningkatnya persaingan yang semakin ketat yang terjadi dibidang industri jasa, khususnya jasa perhotelan. Hotel bukan hanya memberikan akomodasi penginapan tapi didalamnya ada banyak jasa yang ditujukan khusus untuk orang yang menginap. Dengan tersedianya fasilitas-fasilitas penunjang akan mengakibatkan berkembangnya kegiatan operasi hotel. Keberhasilan dari industri jasa ini dapat dinilai dari kepuasan pelanggan yang menggunakan jasa tersebut.

Untuk mempertahankan kelangsungan hidupnya, suatu perusahaan harus dapat mencapai tujuannya yaitu memperoleh laba maksimum. Biaya yang dikeluarkan oleh perusahaan harus benar-benar biaya yang memberi nilai tambah bagi produk sehingga tidak akan ada pemborosan biaya. Oleh karena itu, efisiensi biaya mempunyai arti penting bagi perusahaan dalam mempertahankan keberadaannya di dunia bisnis, juga dalam upaya menghadapi persaingan global yang semakin tajam. Pengelolaan aktivitas (activity based management) merupakan suatu proses pengidentifikasian aktivitas yang dijalankan oleh perusahaan, penentuan nilainya bagi perusahaan, pemilihan serta pelaksanaan aktivitas yang menambah nilai bagi konsumen, mengidentifikasikan atau menghilangkan semua aktivitas tak bertambah nilai dan memperbaiki aktivitas bernilai tambah sehingga menghasilkan penurunan biaya. Pengidentifikasian aktivitas dapat dibagi menjadi dua yaitu, aktivitas yang benilai tambah (value added activity) dan aktivitas yang tak bernilai tambah (non value added 
activity). Metode untuk mengelola aktivitas tersebut dinamakan manajemen berdasarkan aktivitas (Activity Based Management).

\section{TINJAUAN PUSTAKA}

\subsection{Akuntansi Manajemen}

Akuntansi Manajemen adalah proses identifikasi, pengukuran, pengumpulan, analisis, penyiapan dan komunikasi informasi finansial yang digunakan oleh manajemen untuk perencanaan, evaluasi, pengendalian dalam suatu organisasi, serta untuk menjamin ketepatan sumber-sumber dan pertanggung jawaban sumber-sumber tersebut. Akuntansi mempunyai peranan yang sangat penting dalam dunia usaha, mulai dari badan usaha kecil yang tidak mencari keuntungan sampai pada perusahaan besar yang mencari keuntungan membutuhkan informasi akuntansi yang digunakan sebagai alat perencanaan, pengawasan serta maupun sebagai dasar pengambilan keputusan.

\subsection{Manajemen Berbasis Aktivitas (Activity Based Management)}

Activity Based Management adalah suatu pendekatan yang terintegrasi di seluruh sistem yang memfokuskan perhatian manajemen pada berbagai aktivitas yang bertujuan meningkatkan nilai bagi pelanggan dan laba yang dihasilkan. Manajemen Berbasis Aktivitas menekankan pada perhitungan biaya berdasarkan aktivitas (activity based costing-ABC) dan analisis proses (Hansen dan Mowen 2014:13).

\subsection{Dimensi Activity Based Management}

Dimensi Activity Based Management terdiri dari 2 dimensi, yaitu:

1. Dimesi Biaya

Dimensi biaya adalah dimensi dalam Activity Based Management yang bertujuan untuk menyempurnakan keakuratan penelusuran biaya pada objek-objek biaya. Dimensi biaya memberikan informasi biaya (costumer). Dimensi biaya mencerminkan kebutuhan organisasi untuk menelusuri sumber-sumber pada aktivitas-aktivitas dan akhirnya membebankannya pada objek-objek untuk menganalisa keputusan-keputusan penting suatu organisasi. Ada tiga tahapan yang digunakan dalam menyempurnakan keakuratan penelusuran biaya pada objek-objek biaya.

2. Dimensi Proses

Dimensi proses memberikan informasi tentang aktivitas-aktivitas apa saja yang ada di dalam perusahaan, mengapa aktivitas itu dilakukan, bagaimana cara kerja aktivitasaktivitas tersebut dan seberapa baik aktivitas itu dilakukan. Dengan dimensi proses para manajer akan dapat terlibat dan menilai perbaikan yang berkelanjutan.

\subsection{Aktivitas}

\subsubsection{Definisi Aktivitas}

Aktivitas adalah setiap kejadian atau transaksi yang merupakan pemicu biaya (cost driver). Aktivitas adalah kumpulan kegiatan yang dilakukan dalam organisasi yang bermanfaat bagi manajer untuk tujuan perencanaan, pengendalian dan pengambilan keputusan.Untuk dapat mengidentifikasi aktivitas-aktivitas yang ada dalam suatu organisasi dibutuhkan observasi dan pencatatan atas work performend tersebut.

\subsubsection{Analisis Aktivitas}

Yang dimaksud dengan analisis aktivitas adalah mengidentifikasikan, menjabarkan dan mengevaluasi aktivitas yang dilakukan oleh organisasi.

Pelaksanaan analisis aktivitas akan dapat menghasilkan tiga hal yaitu:

a. Aktivitas apa yang telah dilakukan

b. Berapa banyak sumber daya yang diperlukan untuk melakukan aktivitas tersebut.

c. Menentukan nilai aktivitas bagi organisasi, termasuk rekomendasi memilih dan mempertahankan aktivitas yang bernilai tambah. 
Inti dari analisis aktivitas adalah eliminasi pemborosan. Dengan dieliminasinya pemborosan, maka biaya dapat dikurangi. Penurunan biaya dapat mengikuti eliminasi pemborosan. Pemborosan dapat diartikan sebagai sesuatu yang tidak bernilai tambah. Sehingga aktivitas yang tidak diperlu merupakan aktivitas yang harus dihilangkan.

\subsubsection{Aktivitas Bernilai Tambah dan Aktivitas Tidak Bernilai Tambah}

Dalam analisis aktivitas disajikan langkah-langkah yang sistematis bagi organisasi untuk mengevaluasi kembali mengenai aktivitas-aktivitasnya dengan mangklasifikasikan semua aktivitas tersebut ke dalam dua bagian yaitu aktivitas yang dapat memberi nilai tambah (value added activity) dan aktivitas yang tidak dapat memberi nilai tambah (NonValue added activity).

\subsubsection{Aktivitas Bernilai Tambah (Value Added Activity)}

Aktivitas yang memberi nilai tambah adalah aktivitas yang memberi kontribusi terhadap nilai pelanggan dan memberikan kepuasan kepada pelanggan atau organisasi yang membutuhkannya. Aktivitas bernilai tambah merupakan aktivitas-aktivitas yang memang seharusnya dilakukan dan benar-benar diperlukan dalam penyediaan produk untuk memenuhi kebutuhan konsumen dan pencapaian tujuan manajemen perusahaan. Misalnya, aktivitas perancangan produk, pemrosesan oleh tenaga kerja langsung, penambahan bahan langsung, dan aktivitas yang berkaitan dengan mesin dan pengiriman produk.

\subsubsection{Aktivitas Tidak Bernilai Tambah (Non Value Added Activity)}

Aktivitas tidak bernilai tambah adalah aktivitas yang tidak memberikan kontribusi terhadap nilai konsumen atau terhadap kebutuhan organisasi. Aktivitas tidak bernilai tambah adalah semua aktivitas selain berbagai aktivitas yang paling penting untuk tetap bertahan sehingga dipandang tidak perlu (Hansen dan Mowen, 2012:238).

\subsubsection{Karakteristik Aktivitas Bernilai Tambah dan Aktivitas Tidak Bernilai Tambah}

Aktivitas dikatakan mempunyai nilai tambah apabila berupa aktivitas kebijakan yang harus memenuhi persyaratan sebagai berikut :

a. Aktivitas yang dapat menimbulkan perubahan kondisi

b. Perubahan itu tidak dapat dicapai oleh aktivitas sebelumnya.

c. Aktivitas ini memungkinkan aktivitas lainnya dapat dilakukan (Hansen dan Mowen 2012:339).

Aktivitas dapat dikatakan aktivitas tidak bernilai tambah apabila tidak memenuhi salah satu kriteria aktivitas bernilai tambah diatas.

\subsection{Pengurangan Biaya (Cost Reduction)}

Cost Reduction merupakan rangkaian aktivitas yang didesain untuk merubah metode operasi sehingga dapat mencapai standar biaya yang lebih rendah. Cost reduction merupakan otomatisasi dari tindakan analisis terhadap aktivitas-aktivitas yang tidak bernilai tambah sehingga cost reduction disini tidak dimaksudkan sebagai cost cutting melainkan sebagai cost management. Cost management merupakan suatu bentuk pengelolaan proses mulai dari tahap pengkonsepan jasa dan rancangannya, tujuan, permintaan dan kemudian dilanjutkan pada sekelompok aktivitas untuk menyajikan jasa yang akan ditawarkan tersebut.

\subsection{Pengertian Hotel}

Hotel merupakan suatu bentuk badan usaha yang bergerak di bidang jasa penginapan yang dikelola secara komersial dan memerlukan pengelolaan secara profesional terhadap sumber dana dan sumber daya manusia dalam meghasilkan jasa dengan biaya yang efisien. Perusahaan jasa perhotelan memerlukan informasi akuntansi manajemen yang akurat, relevan dan tepat waktu. Penerapan activity based management mampu membantu perusahan perhotelan memperoleh informasi yang relevan dan sistem manajemen biaya yang baru ini juga mampu berperan dalam meningkatkan keakuratan pengendalian biaya. 


\subsection{Efisiensi}

Efisiensi merupakan suatu ukuran keberhasilan yang dinilai dari segi besarnya sumber atau biaya untuk mencapai hasil dari kegiatan yang dijalankan. Dan menjadi perbandingan yang terbaik antara input (masukan) dan output (hasil antara keuntungan dengan sumbersumber yang dipergunakan), seperti halnya juga hasil optimal yang dicapai dengan penggunaan sumber yang terbatas. Dengan kata lain hubungan antara apa yang telah diselesaikan.

\subsection{Penelitian Terdahulu}

Meiny Parengkuan tahun 2013 dengan judul Identifikasi Non Value Added Activity Melalui Activity Based Management Untuk Meningkatkan Efisiensi Hotel Sedona Manado. Hasil Penelitian menunjukan bahwa penerapan ABM layak untuk diterapkan karena dengan penerapan metode tersebut terjadi efisiensi biaya sehingga akan memberi keuntungan bagi pihak hotel tanpa mengurangi jasa yang diterima pelanggan.

\section{METODE PENELITIAN}

\subsection{Jenis dan sumber data}

\subsubsection{Jenis Data}

Jenis data yang digunakan dalam penelitian ini adalah :

1. Data kualitatif dalam penelitian ini berupa gambaran umum tentang sejarah dan struktur instansi Hotel Gran Central Manado. Data kualitatif merupakan data yang disajikan dalam bentuk uraian struktur organisasi dari Hotel Gran Central Manado

2. Data kuantitatif dalam penelitian ini berupa laporan biaya pengeluaran divisi room pada Hotel Gran Central Manado pada tahun 2017. Data kuantitatif merupakan tata cara penelitian yang menghasilkan bentuk angka-angka.

\subsubsection{Sumber Data}

Sumber data yang digunakan dalam penelitian ini adalah data primer dan data sekunder. Data primer dalam penelitian ini adalah data hasil wawancara langsung dengan accounting department Hotel Gran Central Manado. Sedangkan, data sekunder yaitu peneliti mengambil data dengan menggunakan studi literatur yang dilakukan terhadap banyak buku dan diperoleh berdasarkan catatan-catatan yang berhubungan dengan penelitian.

\subsection{Tempat dan Waktu Penelitian}

Penelitian ini dilakukan di Hotel Gran Central Manado yang merupakan salah satu perusahan perhotelan, terletak di Jalan Jendral Sudirman Nomor 123, Pinaesaan, Wenang, Kota Manado, Sulawesi Utara. Waktu penelitian dilaksanakan pada bulan maret tahun 2018.

\subsection{Metode analisis}

Metode analisis data yang digunakan dalam penelitian ini adalah metode analisis kualitatif deskriptif. Langkah-langkah yang berkaitan dengan penyusunan laporan biaya pengeluaran divisi room tahun 2017 adalah :

1. Pengumpulan data, data yang dikumpulkan berupa data laporan biaya pengeluaran divisi room tahun 2017.

2. Penyajian data, dalam hal ini penulis menganalisis laporan biaya pengeluaran divisi room tahun 2017 dari hasil wawancara Accounting department. Kemudian akan disusun secara sistematis sesuai dengan data yang diperoleh dan jawaban atas pertanyaan-pertanyaan yang diberikan kepada narasumber tersebut.

3. Pengambilan keputusan, berdasarkan hasil analisis dan wawancara diambil penarikan kesimpulan dan saran-saran yang diperlukan. 


\section{HASIL ANALISIS DAN PEMBAHASAN}

\subsection{Hasil analisis}

Penyajian Data Biaya Divisi Room Hotel Gran Central Manado 2017

Biaya-biaya divisi room hotel ini timbul dari semua biaya yang berkaitan dengan aktivitas pemberian jasa penginapan yaitu mulai dari departemen front office yang terdiri atas unit aktivitas administrasi, concierge serta dari departemen housekeeping yang terdiri atas unit aktivitas housekeeping and laundry.

Data biaya divisi room selama tahun 2017 ini diperoleh dari bagian Accounting hotel dimana biaya ini melalui berbagai pola perkiraan telah disusun untuk tujuan pembuatan laporan keuangan yang ditujukan bagi pihak manajemen hotel.

Tabel 1. Biaya-biaya Divisi Room Hotel Gran Central Manado Tahun 2017

\begin{tabular}{|l|r|}
\hline \multicolumn{1}{|c|}{ Jenis Biaya } & \multicolumn{1}{|c|}{ Jumlah Biaya (Rp) } \\
\hline Salaries & 850.360 .000 \\
\hline Cleaning Supplies & 9.125 .000 \\
\hline Guest Supplies & 81.986 .892 \\
\hline Laundry and Dry Cleaning & 19.734 .876 \\
\hline Phone and Internet & 32.250 .000 \\
\hline Printing and Stationary & 40.973 .650 \\
\hline Guest and Local Transportation & 7.114 .345 \\
\hline Postage & 260.000 \\
\hline Maintenance & 48.825 .850 \\
\hline Total Biaya & $\mathbf{1 . 0 9 0 . 6 3 0 . 6 1 3}$ \\
\hline
\end{tabular}

(Sumber : data olahan)

\section{Analisis Cost Driver}

Untuk menelusuri biaya ke masing-masing unit aktivitas, diperlukan suatu penentuan cost driver. Cost driver itu sendiri terdiri dari 2 jenis yaitu resources driver yang melekat pada biaya itu sendiri dan activity driver yang melekat pada aktivitas itu sendiri. Dengan adanya suatu cost driver yang tepat maka biaya tersebut dapat dialokasikan secara tepat ke masing-masing unit aktivitas. Setelah mengetahui ratio konsumsi pemicu biaya pada masingmasing unit aktivitas 2012 maka dilakukan pengalokasian biaya pada masing-masing unit aktivitas. Perincian alokasi biaya ke masing-masing unit aktivitas ditunjukkan pada Tabel 2 berikut.

Tabel 2. Rincian Alokasi Biaya Divisi Room Tahun 2017

\begin{tabular}{|l|r|r|r|r|}
\hline \multicolumn{1}{|c|}{ Jenis Biaya } & Administrasi & Concierge & \multicolumn{1}{c|}{$\begin{array}{c}\text { Housekeeping } \\
\text { and Laundry }\end{array}$} & \multicolumn{1}{c|}{ Total } \\
\hline Salaries & 303.748 .592 & 212.590 .000 & 334.021 .408 & 850.360 .000 \\
\hline Cleaning Supplies & & & 9.125 .000 & 9.125 .000 \\
\hline Guest Supplies & & & 81.986 .892 & 81.986 .892 \\
\hline $\begin{array}{l}\text { Laundry and Dry } \\
\text { Cleaning }\end{array}$ & & & 19.734 .876 & 19.734 .876 \\
\hline Phone and Internet & 16.125 .000 & 13.448 .250 & 2.676 .750 & 32.250 .000 \\
\hline Printing and Stationary & 29.541 .533 & & 11.431 .467 & 40.973 .000 \\
\hline $\begin{array}{l}\text { Guest and Local } \\
\text { Transportation }\end{array}$ & & 7.114 .345 & & 7.114 .345 \\
\hline Postage & & 260.000 & & 260.000 \\
\hline Maintenance & 4.574 .982 & 6.103 .231 & 38.147 .636 & 48.825 .850 \\
\hline Total Biaya & $\mathbf{3 5 3 . 9 9 0 . 1 0 7}$ & $\mathbf{2 3 2 . 1 4 1 . 4 8 1}$ & $\mathbf{4 9 7 . 1 2 4 . 0 2 9}$ & $\mathbf{1 . 0 9 0 . 6 2 9 . 9 6 3}$ \\
\hline
\end{tabular}

(Sumber : data olahan) 


\section{Pengalokasian Biaya Ke Aktivitas}

Setelah menentukan cost driver untuk masing-masing biaya dan alokasi biaya untuk tiap unit aktivitas yang ada maka pengalokasian besarnya biaya untuk masing-masing aktivitas dapat dilakukan. Pembebanan biaya ke tiap-tiap aktivitas ini ditentukan berdasarkan persentase dimana persentase tersebut diperoleh dengan cara membagi jumlah cost driver masing-masing aktivitas dengan jumlah cost driver tiap unit aktivitasnya.

Tabel 3. Biaya Aktivitas Divisi Room Hotel Gran Central Manado Tahun 2017

\begin{tabular}{|l|r|}
\hline \multicolumn{1}{|c|}{ Jenis Aktivitas } & \multicolumn{1}{|c|}{ Biaya Aktivitas } \\
\hline Unit Aktivitas Administrasi & 33.358 .553 \\
\hline Supervise Front Office & 148.871 .474 \\
\hline Administrasi check-in, check-out and payment & 35.148 .698 \\
\hline Deposit Reservation & 31.843 .073 \\
\hline Room Numbering Block & 34.826 .768 \\
\hline Reservation Call Book and Blocking & 39.969 .803 \\
\hline Reservation Confirmation & 30.374 .859 \\
\hline Arrangement Room Occupied & \\
\hline Unit Aktivitas Concierge & 60.736 .963 \\
\hline Membukakan pintu mobil tamu & 60.736 .963 \\
\hline Membawakan tas tamu dan mengantar tamu ke kamar & 87.402 .789 \\
\hline Melayani tamu dari dan ke bandara atau stasiun & 30.617 .852 \\
\hline Menangani masalah tamu yang pernah menginap & 37.035 .175 \\
\hline Unit Aktivitas Housekeeping and Laundry & 181.054 .300 \\
\hline Supervise Housekeeping & 88.483 .665 \\
\hline Mempersiapkan kamar dan membersihkan kamar & 71.998 .425 \\
\hline Membersihkan area yang terletak di sekitar kamar & 78.721 .783 \\
\hline Melayani pencucian pakaian tamu & 39.706 .793 \\
\hline Menangani pencucian linen & $\mathbf{1 . 0 9 0 . 6 3 0 . 6 1 3}$ \\
\hline Inspeksi kamar & \\
\hline TOTAL &
\end{tabular}

(Sumber : data olahan)

\section{Analisis Aktivitas}

Setelah perhitungan pembebanan biaya ke produk diketahui maka dilakukan analisis terhadap aktivitas divisi room Hotel Gran Central Manado. Hal ini dilakukan untuk menentukan aktivitas apa saja yang bernilai tambah dan aktivitas apa saja yang tidak memberikan nilai tambah. Untuk mengklasifikasikan aktivitas ini menjadi aktivitas bernilai tambah atau tidak bernilai tambah, maka sesuai dengan teori yang menjelaskan bahwa aktivitas bernilai tambah merupakan aktivitas yang secara simultan memenuhi tiga kondisi berikut ini yaitu :

1. Aktivitas tersebut menghasilkan suatu perubahan.

2. Perubahan tersebut tidak dapat dicapai oleh aktivitas yang sebelumnya.

3. Aktivitas tersebut memungkinkan aktivitas lain untuk dilakukan.

Aktivitas yang tergolong non value added activities (NVA) adalah :
1. Room Numbering Block
2. Reservation Confirmation
3. Arrangement Room Occupied
4. Inspeksi kamar 
Pada tabel berikut akan ditampilkan jumlah biaya yang telah diklasifikasikan menjadi dua menurut analisis aktivitas yaitu value added activities (VA) dan non value added activities (NVA). Untuk selanjutnya, dari pengelompokkan biaya ini nantinya akan dilakukan penggabungan, pengeliminasian atau pereduksian beberapa aktivitas sehingga biaya tidak bernilai tambah yang muncul di divisi room Hotel Gran Central Manado ini dapat dikurangi.

Tabel 4. Biaya Value Added Activities dan Non Value Added Activities

\begin{tabular}{|c|c|c|c|}
\hline Jenis Aktivitas & VA & NVA & Total \\
\hline \multicolumn{4}{|l|}{ Unit Aktivitas Administrasi } \\
\hline$\overline{\text { Supervise Front Office }}$ & 33.358 .553 & & 33.358 .553 \\
\hline $\begin{array}{l}\text { Administrasi check-in, check-out } \\
\text { and payment }\end{array}$ & 148.871 .474 & & 148.871 .474 \\
\hline Deposit Reservation & 35.148 .698 & & 35.148 .698 \\
\hline Room Numbering Block & & 31.843 .073 & 31.843 .073 \\
\hline $\begin{array}{l}\text { Reservation Call Book and } \\
\text { Blocking }\end{array}$ & 34.826 .768 & & 34.826 .768 \\
\hline Reservation Confirmation & & 39.969 .803 & 39.969 .803 \\
\hline Arrangement Room Occupied & & 30.374 .859 & 30.374 .859 \\
\hline \multicolumn{4}{|l|}{ Unit Aktivitas Concierge } \\
\hline Membukakan pintu mobil tamu & 60.736 .963 & & 60.736 .963 \\
\hline $\begin{array}{l}\text { Membawakan tas tamu dan } \\
\text { mengantar tamu ke kamar }\end{array}$ & 60.736 .963 & & 60.736 .963 \\
\hline $\begin{array}{l}\text { Melayani tamu dari dan ke } \\
\text { bandara atau stasiun }\end{array}$ & 87.402 .789 & & 87.402 .789 \\
\hline $\begin{array}{l}\text { Menangani masalah tamu yang } \\
\text { pernah menginap }\end{array}$ & 30.617 .852 & & 30.617 .852 \\
\hline \multicolumn{4}{|l|}{$\begin{array}{l}\text { Unit Aktivitas Housekeeping } \\
\text { and Laundry }\end{array}$} \\
\hline Supervise Housekeeping & 37.035 .175 & & 37.035 .175 \\
\hline $\begin{array}{l}\text { Mempersiapkan kamar dan } \\
\text { membersihkan kamar }\end{array}$ & 181.054 .300 & & 181.054 .300 \\
\hline $\begin{array}{l}\text { Membersihkan area yang terletak } \\
\text { di sekitar kamar }\end{array}$ & 88.483 .665 & & 88.483 .665 \\
\hline $\begin{array}{l}\text { Melayani pencucian pakaian } \\
\text { tamu }\end{array}$ & 71.998 .425 & & 71.998 .425 \\
\hline Menangani pencucian linen & 78.721 .783 & & 78.721 .783 \\
\hline Inspeksi kamar & & 39.706 .793 & 39.706 .793 \\
\hline TOTAL & 948.736 .085 & 141.894 .528 & 1.090.630.613 \\
\hline
\end{tabular}

(Sumber : data olahan) 
Pengurangan Biaya (Cost Reduction)

Tabel 5. Biaya Aktivitas Tidak Bernilai Tambah Divisi Room Hotel Gran Central Manado Tahun 2017 Setelah Cost Reduction

\begin{tabular}{|l|r|c|r|}
\hline $\begin{array}{c}\text { Aktivitas Tidak Bernilai } \\
\text { Tambah (NVA) }\end{array}$ & Biaya Aktivitas & \% Cost Reduction & \multicolumn{1}{|c|}{$\begin{array}{c}\text { Besar Cost } \\
\text { Reduction }\end{array}$} \\
\hline Room Numbering Block & 31.843 .073 & $100 \%$ & 31.843 .073 \\
\hline Reservation Confirmation & 39.969 .803 & $100 \%$ & 39.969 .803 \\
\hline $\begin{array}{l}\text { Arrangement Room } \\
\text { Occupied }\end{array}$ & 30.374 .859 & $100 \%$ & 30.374 .859 \\
\hline Inspeksi Kamar & 39.706 .793 & $100 \%$ & 39.706 .793 \\
\hline Total & 141.894 .528 & & 141.894 .528 \\
\hline
\end{tabular}

(Sumber : data olahan)

Dari pengeliminasian aktivitas tidak bernilai tambah tersebut, maka biaya aktivitas yang timbul di divisi room Hotel Gran Central Manado ini tentu saja akan berkurang. Total pengurangan biaya ini dapat dilihat pada tabel berikut.

Tabel 6. Biaya Aktivitas Divisi Room Hotel Gran Central Manado Tahun 2017 Setelah Cost Reduction

\begin{tabular}{|l|r|}
\hline \multicolumn{1}{|c|}{ Jenis Aktivitas } & \multicolumn{1}{|c|}{ Biaya Aktivitas } \\
\hline Unit Aktivitas Administrasi & 33.358 .553 \\
\hline Supervise Front Office & 148.871 .474 \\
\hline Administrasi check-in, check-out and payment & 35.148 .698 \\
\hline Deposit Reservation & 34.826 .768 \\
\hline Reseravtion Call Book and Blocking & 60.736 .963 \\
\hline Unit Aktivitas Concierge & 60.736 .963 \\
\hline Membukakan pintu mobil tamu & 87.402 .789 \\
\hline Membawakan tas tamu dan mengantar tamu ke kamar & 30.617 .852 \\
\hline Melayani tamu dari dan ke bandara atau stasiun & 37.035 .175 \\
\hline Menangani masalah tamu yang pernah menginap & 181.054 .300 \\
\hline Unit Aktivitas Housekeeping and Laundry & 88.483 .665 \\
\hline Supervise Housekeeping & 71.998 .425 \\
\hline Mempersiapkan kamar dan membersihkan kamar & 78.721 .783 \\
\hline Membersihkan area yang terletak di sekitar kamar & $\mathbf{9 4 8 . 7 3 6 . 0 8 5}$ \\
\hline Melayani pencucian pakaian tamu & \\
\hline Menangani pencucian linen & \\
\hline Total & \\
\hline Sumber : & \\
\hline
\end{tabular}

(Sumber : data olahan)

Dengan menggunakan Activity Based Management maka total biaya di divisi room Hotel Gran Central Manado dapat berkurang sebanyak Rp.141.363.737,- dari Rp.1.090.630.613,- menjadi Rp. 948.736.085,-

\subsection{Pembahasan}

Dari hasil analisa sebelumnya nampak bahwa ada beberapa aktivitas yang dapat digabungkan dengan aktivitas lain yang sejenis, direduksi volume aktivitasnya atau bahkan ada yang perlu untuk dieliminasi. Aktivitas tersebut antara lain :

1. Room Numbering Block

Aktivitas ini adalah aktivitas memberi tanda untuk nomor kamar yang ditempati oleh tamu dan aktivitas ini hampir sama dengan aktivitas reservation call book and blocking 
sehingga aktivitas ini tidak bernilai tambah, oleh karena itu aktivitas ini dapat dieliminasi karena merupakan bentuk pengulangan dari aktivitas reservation call book and blocking sehingga biayanya dapat dieliminasi $100 \%$. Aktivitas ini termasuk dalam aktivitas membuat skedul.

\section{Reservation Confirmation}

Aktivitas ini adalah aktivitas untuk melakukan konfirmasi ulang kepada tamu yang akan menginap di hotel. Aktivitas ini juga dapat dieliminasi karena sama dengan aktivitas reservation call book and blocking sehingga aktivitas reservation confirmation ini hanya menghasilkan biaya tidak bernilai tambah. Dengan adanya pengeliminasian aktivitas ini maka biaya yang muncul juga dieliminasi sebanyak 100\%. Aktivitas ini termasuk dalam aktivitas membuat skedul.

\section{Arrangement Room Occupied}

Aktivitas ini merupakan aktivitas untuk mangatur kamar setelah tamu tiba di hotel. Aktivitas ini dieliminasi karena jika pihak hotel telah memastikan dengan jelas kepada pihak pemesan kamar mengenai jumlah kamar yang akan dihuni oleh tamu pada saat tamu tersebut melakukan reservasi maka pihak hotel dapat memperoleh informasi mengenai jumlah kamar yang akan disediakan untuk tamu yang memesan kamar sehingga aktivitas ini dapat dieliminasi sebesar $100 \%$. Aktivitas ini termasuk dalam aktivitas membuat skedul.

4. Inspeksi kamar

Aktivitas ini adalah aktivitas untuk memeriksa keadaan kamar, apakah ada yang rusak atau tidak. Aktivitas ini dapat dieliminasi karena aktivitas ini telah dilakukan oleh aktivitas lain yaitu aktivitas supervise housekeeping sehingga dapat dieliminasi $100 \%$ langsung. Aktivitas ini termasuk dalam aktivitas melakukan inspeksi.

\section{KESIMPULAN DAN SARAN}

\subsection{Kesimpulan}

Dari analisis menggunakan metode Activity Based Management (ABM) terhadap aktivitas-aktivitas yang ada di divisi room Hotel Gran Central Manado ini, maka dapat diidentifikasikan aktivitas-aktivitas apa saja yang tergolong aktivitas aktivitas bernilai tambah dan aktivitas tidak bernilai tambah. Pada divisi room terdapat beberapa aktivitas tidak bernilai tambah yang menyebabkan timbulnya biaya tidak bernilai tambah yaitu sebesar Rp. Rp.141.363.737,--. Setelah dilakukan manajemen aktivitas maka biaya tidak bernilai tambah tersebut akhirnya dapat direduksi, maka dapat disimpulkan bahwa penerapan activity based management (ABM) sangat layak untuk diterapkan karena dengan penerapan metode tersebut terjadi efisiensi biaya pada Hotel Gran Central Manado sehingga hal ini akan memberi keuntungan bagi pihak hotel tanpa mengurangi jasa yang diterima oleh pelanggan.

\subsection{Saran}

Berdasarkan kesimpulan tersebut, maka saran-saran yang dapat diberikan kepada pihak Hotel Gran Central Manado, yaitu :

1. Untuk mencapai efisiensi biaya, maka pihak manajemen hotel sebaiknya berfokus pada pengelolaan aktivitas melalui penerapan Activity Based Management (ABM) supaya dapat diperoleh informasi mengenai aktivitas mana saja yang tergolong bernilai tambah atau tidak bernilai tambah sehingga pemakaian sumber daya yang tidak efisien oleh aktivitas tidak bernilai tambah tersebut dapat direduksi atau dieliminasi.

2. Beberapa tindakan alternatif yang dapat dilakukan oleh manajemen Hotel Gran Central Manado sebagai upaya untuk menggabungkan aktivitas sejenis, mereduksi atau bahkan mengeliminasi aktivitas tidak bernilai tambah di divisi room agar tercipta efisiensi biaya. 


\section{DAFTAR PUSTAKA}

Afian, Gunarso. (2015). Analisis penggunaan Activity Based Management (ABM) untuk meningkatkan efisiensi produksi dan profitabilitas pada perusahaan tahu UD. $3 S^{\prime}$ Prima Kota Batu. Penelitian yang tidak dipublikasikan. Fakultas Ekonomis dan Bisnis. Universitas Brawijaya. Malang.

Danesha Faradina. (2017). Peranan Strategic Activity Based Management dalam meningkatkan profitabilitas pelanggan pada PT. Sinar Sosro KP Cimahi. Penelitian yang tidak dipublikasikan. Fakultas Ekonomi dan Bisnis. Universitas Katolik Parahyangan. Bandung.

Hansen dan Mowen. 2014. Akuntansi Manajemen. Edisi 8. Jakarta. Penerbit Salemba Empat.

Hendro Suseno (2016). Metode Activity Based Management (ABM) pada Hotel Aston Imperium Purwokerto. Penelitian yang tidak dipublikasikan. Fakultas Ekonomi dan Bisnis. Universitas Muhammadiyah Malang.

Kalonio, Poputra, Tirayoh. (2017). Penerapan Manajemen Berbasis Aktivitas untuk meningkatkan Efisiensi Biaya pada Whiz Prime Hotel Megamass Manado. Jurnal Riset Akuntansi going concern 12(2), 2017, 565-574. Fakultas Ekonomi dan Bisnis. Universitas Sam Ratulangi. Manado.

Karina, Widyani. (2015). Analisis Penerapan Metode Activity Based Management (ABM) untuk meningkatkan efisiensi dan profitabilitas pada PT.Perkebunan Nusantara IX Pabrik Gula Mojo Sragen. Penelitian yang tidak dipublikasikan. Fakultas Ekonomi dan Bisnis Universitas Muhammadiyah. Surakarta.

Meiny Parengkuan. 2013. Identifikasi Non Value Added Activity melalui Activity Based Management untuk meningkatkan Efisiensi Hotel Sedona Manado. Jurnal EMBA Vol.1 No.3 September 2013 Hal.109-117. Fakultas Ekonomi dan Bisnis. Universitas Sam Ratulangi Manado.

Riza, Purnamasari (2013). Analisis Activity Based Management dalam peningkatan Efisiensi Biaya produksi pada seksi pulp making-9 pada PT. Indah Kiat Pulp and Paper Pelawang. Penelitian yang tidak dipublikasikan. Fakultas Ekonomi Universitas Islam Negeri Sultan Syarif Kasim Riau Pekanbaru.

Siti Eka Fariyani (2012). Efisiensi biaya produksi dengan metode Activity Based Managemnt $(A B M)$. Skripsi. Fakultas Ekonomi. Universitas Gunadarma.

Sitorus, Poputra, Runtu. (2014). Penerapan Activity Based Management untuk meningkatkan Efisiensi pada Hotel Sahid Kawanua Manado. Jurnal EMBA Vol.2 No.3 September 2014, Hal. 1001-1009.Fakultas Ekonomi dan Bisnis Universitas Sam Ratulangi. Manado.

Widarti, Nazaruddin, Anizar. (2013). Peningkatan Efisiensi Biaya Produksi dengan metode Activity Based Management pada PT.XTZ. e-journal teknik industry FT Usu Vol.4 No.1 Oktober 2013 pp 1-5. Fakultas Teknik. Universitas Sumatra Utara. Medan. 